\title{
VÁLLALKOZÓI KUDARC
}

\author{
A VÉG, VAGY EGY ÚJ KEZDET?
}

A szerző szerint jelen felderítő kvalitatív kutatás célja a vállalkozók kudarcra adott reakcióinak és a folyamatra ható tényezőknek a megismerése volt. A vizsgálat három fő részből állt: vállalkozói attitűdök (szemléletmódok, kontrollhely, időperspektívák), környezeti hatások (vállalkozók általános megítélése, stigmatizáció), valamint a kudarcra adott vállalkozói reakciók (a kudarc késleltetése, gyász, tanulás a kudarcból). A szerző a kutatás során egyaránt felhasználta a 8 fős, legalább egy kudarcot átélt, vállalkozói mintával készült mélyinterjúkból származó primer információkat és a kapcsolódó szekunder adatokat is. A vállalkozói attitűdöknél többek között megerősítést nyert az, hogy a vállalkozók általában belső kontrollosak, de egy kellően nagy kudarc ezt megváltoztathatja. Az interjúalanyok fele tapasztalt stigmatizációt a legjelentősebb kudarcuk kapcsán. A tanulmány egyaránt bemutatja a gyász mértékét növelő (erőteljes múltnegativitás, stigmatizáció) és csökkentő tényezőket (rendelkezésre álló portfólió). Csak egy vállalkozó nem vont le tanulságot, míg a többiek igen, sőt hárman eleve tanulási folyamatként tekintenek a vállalkozásra.*

Kulcsszavak: vállalkozói kudarc, stigmatizáció, tanulás a kudarcból, gyász, szemléletmódok, időperspektívák, kontrollhely

$\mathrm{S}_{\mathrm{in}}^{\mathrm{ik}}$ kereinkről szívesebben beszélünk, mint kudarcainkról és a kutatások többsége is inkább azt vizsgálja, hogy mitől vagy hogyan lesz sikeres egy személy vagy egy vállalkozás. Azonban, szerintem legalább olyan fontos, hogy figyelmet szenteljünk annak is, hogy mi történik az egyénnel, amikor kudarc éri, hogyan reagál erre ô és a környezetében élők. A vállalkozók esetében, úgy gondolom a téma aktualitása még jelentősebb, hiszen a vállalkozói lét egyik alapeleme a bizonytalanság és a kockázat, melyek gyakran magukkal hordozzák a kudarcot is (McGrath, 1999; Shepherd - Patzelt, 2017). A Központi Statisztikai Hivatal (2017) adatai szerint a 2000-es években Magyarországon évente átlagosan megközelítőleg 68.000 vállalkozást szüntettek meg jogutód nélkül, mely érték a müködő vállalkozások megközelítőleg $10 \%$-a. Továbbá a társas vállalkozások ötéves túlélési rátája $45,1 \%$ volt 2015 ben, míg az egyéni vállalkozóké csupán 27,1\%.

Shepherd és Patzelt (2017) szerint nem csak a vállalkozóknak, de az őket vizsgáló kutatóknak is úttörőknek kell lenniük, hogy jobban megérthessék a vállalkozókat. Véleményük szerint, ezért nem egyre szükebb réteget célzó kutatásokra van szükség, hanem a vállalkozástant új irányok, eredmények felé terelő témákra és a kutatók részéröl is vállalkozói szemléletre. Könyvükben több olyan területet jelölnek meg, melyek alkalmasak lehetnek úttörö kutatásokra és a jövőben fontos eredmények emelkedhetnek ki közülük. Az egyik ilyen témakör a vállalkozói kudarcoké.

A kutatók abban egyet értenek, hogy a kudarc gyakran fájdalmas és traumatikus tapasztalat lehet a vállalkozók számára (Cope, 2011; Shepherd, 2003; Singh et al., 2015; Ucbasaran et al., 2013) és az érzelmi részen túlmenően számos negatív következménnyel is járhat (Cope, 2011; Ucbasaran et al., 2013). Azonban nem minden kudarc tel- jes egészében negatív, például termékfejlesztés során jobb megoldások felé terelhet (Shepherd - Patzelt, 2017). Ráadásul a kudarc során a vállalkozók egyedi információkat, tapasztalatokat szerezhetnek és a felépülés felfogható egyfajta tanulási folyamatként is (Cope, 2011; Cotterill, 2012; McGrath, 1999; Shepherd - Patzelt, 2017; Sitkin, 1992; Ucbasaran et al., 2013).

A fentiek alapján jelen feltáró kutatásban arra a komplex kérdésre kerestem a választ, hogy a kudarcot átélt vállalkozók miként reagálnak a kudarcélményre és milyen kapcsolatok feltételezhetők e reakciók, a releváns vállalkozói attitűdök és egyes külső környezeti tényezők között. A kutatással az volt a célom, hogy a szakirodalomban fellelhető elméleteket felhasználva létrehozzak, és egy kis magyar vállalkozói mintán kipróbáljak egy olyan modellt, amely bemutatja a vállalkozói kudarc legfontosabb tényezőit és összefüggéseit.

\section{A kutatás alapfogalmai}

Egy több kutató által is elfogadott definíció szerint a $k u$ darc nem más, mint azon vállalkozás bezárása, amely elmaradt a céljaitól, vagy nem tudta a tulajdonosi elvárásokat kielégíteni (Cope, 2011; McGrath, 1999; Ucbasaran et al., 2010). E definícióból is érződik, hogy a vállalkozás bezárása nem minden esetben azonos az üzleti kudarccal (Cope, 2011; Simmons et al., 2014; Ucbasaran et al., 2010). Objektív módon a vállalkozás megszűntetése, csődje jelentheti a kudarcot, míg szubjektív módon az eredmény és a cél eltérése (McKenzie - Sub, 2008), azaz az objektív része a kudarcnak a vállalkozó saját véleményétől, hozzáállásától független, addig a szubjektív része erősen függ a vállalkozó által támasztott elvárásoktól. A Global Entrepreneurship Monitor (továbbiakban GEM) kutatása-

* Köszönetnyilvánítás:

Ezúton szeretném megköszönni Farkas Gergelynek (SZTE-GTK) a XXXIII. OTDK alatti témavezetését, melynek eredménye e tanulmány alapját képező, 1. helyezet dolgozat lett. Továbbá köszönöm Dr. habil. Málovics Evának (SZTE-GTK) a tanulmányhoz füzött konstruktív megjegyzéseit. 
iban kitér arra, hogy miért lépnek ki vállalkozásaikból a megkérdezettek, mely következtetni engedhet a kudarcok okaira is. 2015-ös adataik szerint Magyarországon az öt fö kilépési ok a profithiány, a bürokrácia, a finanszírozási problémák, a jobb lehetőség és a magánéleti ok (Kelley et al., 2016). Kutatásomban azonban a fenti definícióknál kicsit tágabban értelmeztem a kudarcot, mint azt a GEM kutatásai is sugallják. Hiszen vállalkozói kudarc az is, ha valamilyen okból a vállalkozó a vállalkozása elhagyására kényszerül (például: probléma az üzlettársakkal) vagy a kilépés mellett dönt, mivel a vállalkozás nem teljesítette az elvárásait, függetlenül attól, hogy üzlettársai tovább müködtetik-e a vállalkozást.
Az érzelmi költségek terén tapasztalhatunk eltérést a vállalkozói típusok között, hiszen egy sorozatvállalkozó érzelmi költségei vélhetően magasabbak lesznek, mint egy portfólióvállalkozónak, mivel egyszerre csak egy vállalkozáshoz kötődik (Shepherd et al., 2009; Simmons et al., 2014; Ucbasaran et al., 2010). Ez azért is lényeges pont, amelyre a későbbiekben részletesen kitérek még, mert Shepherd (2003) szerint az erőteljes érzelmek és elköteleződés késleltethetik a tanulást egy kudarcélmény után, valamint addig képtelenek a vállalkozók továbblépni és figyelmet, energiát szentelni egy új vállalkozásnak (Shepherd et al., 2009). A szakirodalmi áttekintés rendszerezéséhez Cotterill (2012) csoportosítása adott ötletet, mely alapján a három fö blokk

Területenkénti példák a kudarc következményeire vállalkozók esetében

1. táblázat

\begin{tabular}{|c|c|c|}
\hline Terület & Következmény leírása & Szakirodalmi előfordulás \\
\hline Pénzügyi költség & $\begin{array}{l}\text { A vállalkozók személyes jóléte általában összekötődik a } \\
\text { vállalkozás pénzügyi sikerességével, így annak a kudarca } \\
\text { a személyes jólét csökkenését is jelzi. }\end{array}$ & Shepherd et al. (2009), Ucbasaran et al. (2013) \\
\hline Érzelmi költség & $\begin{array}{l}\text { A kudarcot követően a vállalkozók életét változatos } \\
\text { negatív érzelmek lephetik el a gyász következtében. }\end{array}$ & $\begin{array}{l}\text { Cope (2011), Shepherd (2003), Shepherd et al. } \\
\text { (2009), Singh et al. (2007), Ucbasaran et al. (2013) }\end{array}$ \\
\hline $\begin{array}{l}\text { Pszichológiai } \\
\text { következmény }\end{array}$ & A kudarc általában megingatja a vállalkozó önbizalmát. & $\begin{array}{c}\text { Cope (2011), Shepherd (2003), } \\
\text { Singh et al. (2015) }\end{array}$ \\
\hline $\begin{array}{l}\text { Társadalmi } \\
\text { következmény }\end{array}$ & $\begin{array}{l}\text { Egyes társadalmakban a vállalkozók kudarc esetén } \\
\text { megkapják a „bukott vállalkozó” stigmáját. }\end{array}$ & $\begin{array}{c}\text { Shepherd - Patzelt (2017), Simmons et al. (2014), } \\
\text { Singh et al. (2015), Ucbasaran et al. (2013), } \\
\text { Wiesenfeld et al. (2008) }\end{array}$ \\
\hline $\begin{array}{l}\text { Szakmai } \\
\text { következmény }\end{array}$ & $\begin{array}{l}\text { Elöfordul, hogy a kudarc a vállalkozó személyéhez } \\
\text { kötődik, így szakmailag leértékelődik, minek } \\
\text { következtében a jövőben nehezebben kap álláslehetőséget. }\end{array}$ & $\begin{array}{c}\text { Cardon et al. (2011), Singh et al. (2007), Singh et } \\
\text { al. (2015), Ucbasaran et al. (2013), Wiesenfeld et } \\
\text { al. (2008) }\end{array}$ \\
\hline $\begin{array}{l}\text { Vállalkozói } \\
\text { következmény }\end{array}$ & $\begin{array}{c}\text { Vannak, akiket egy kudarcélmény örökre elrettent a } \\
\text { vállalkozói léttől. }\end{array}$ & $\begin{array}{c}\text { Cardon et al. (2011), Burke et al. (2008), Shepherd } \\
\text { (2003), Singh et al. (2015) }\end{array}$ \\
\hline
\end{tabular}

Forrás: saját szerkesztés Cope (2011) modelljében

A vállalkozók által megélt üzleti kudarcok vizsgálatakor azonban fontos lehet figyelembe venni, hogy volt-e korábbi üzleti, vállalkozói tapasztalatuk (Cope, 2011; Simmons et al., 2014; Ucbasaran et al., 2010), valamint, hogy a kudarcélménykor egy vagy több vállalkozást tulajdonoltak (például: McGrath, 1999; Ucbasaran et al., 2010). A továbbiakban a vállalkozók csoportosítására Ucbasaran és szerzőtársai (2008, p. 323.) által megfogalmazott definíciókat fogom használni. „Kezdő vállalkozók azok a személyek, akiknek nincs korábbi se kisebbségi, se többségi tapasztalata, mint üzleti alapító, vagy mint vásárlója egy független vállalkozásnak...”. A vállalkozói tapasztalattal rendelkezö „szokásos vállalkozókat” két csoportra osztották, sorozatvállalkozókra, akik eladtak vagy bezártak legalább egy vállalkozást, amiben tulajdonosok voltak, és jelenleg tulajdonosai egy független vállalkozásnak, valamint portfólióvállalkozókra, akik jelenleg tulajdonosai kettő vagy több független vállalkozásnak.

Cope (2011) hat területet (pénzügyi, érzelmi, pszichológiai, társadalmi, szakmai és vállalkozói) különített el, ahol jelentős hatást gyakorolhat a kudarc a vállalkozóra, melyek közül néhány - a szakirodalomban is gyakrabban megjelenő - példát mutattam be az 1. táblázatban . a következő: környezeti tényezők, vállalkozói attitüdök, valamint a kudarcra adott vállalkozói reakciók.

\section{A környezeti hatások}

Vállalkozók vizsgálatakor a környezeti hatások kutatása egy izgalmas terület, hiszen e tényezők támogathatják vagy hátráltathatják a vállalkozói aktivitást, melyet számos kutatás kiemelt, még ha eltérö megközelítésben is (Cardon et al., 2011; Cotterill, 2012; Gnyawali - Fogel, 1994; McGrath, 1999; Szerb - Kocsis-Kisantal, 2008; Singh et al., 2015). Egy 2012-es átfogó kutatásban Magyarországon az általános kép a vállalkozókról, mint csoportról 26\%-ban kedvezö, 53\%-ban semleges, valamint 17\%-ban kedvezőtlen, mely értékek alapján, a vállalkozók megítélése Magyarországon az egyik legkedvezőtlenebb a felmért országok közül, olyannyira, hogy a 26\%-os érték a legalacsonyabb, míg a másik két érték vonatkozásában is a három legrosszabba tartoztunk (European Commission, 2012). Megvizsgálva a fenti kutatás további specifikusabb mutatóit is, hasonlóan kedvezőtlen kép jelenik meg hazánkról a vállalkozók megítélésével kapcsolatban.

„A közvélemény alakulásának formálásában kitüntetett szerep jut a médiának, amely nem csupán tudósíthat 
egyes eseményekről..., hanem a hírek révén alakíthatja, formálhatja is a közvéleményt" (Szerb - Kocsis-Kisantal, 2008, p. 246.). A GEM kutatásai is tartalmaznak egy mutatót, melyből látszik, hogy Magyarországon csupán az emberek megközelítőleg egyharmada találkozik sikeres vállalkozókról szóló hírekkel a médiában, mely érték lényegében stagnált az elmúlt években (Szerb - Kocsis-Kisantal, 2008; Amorós - Bosma, 2014; Kelley et al., 2016) és világviszonylatban is a legkedvezőtlenebbek között van (Amorós - Bosma, 2014). Azonban ez az arány médiumonként (televízió, internet, nyomtatott sajtó, rádió) eltérhet (Repisky, 2015). Továbbá a Szerb - Kocsis-Kisantal szerzőpáros (2008) megvizsgálva két hazai folyóirat egy teljes éves vállalkozókkal kapcsolatos híradásait arra a megállapításra jutott, hogy a kudarcokkal, a csődbe ment vállalkozásokkal kapcsolatos híreknek a média nem tulajdonított olyan jelentős figyelmet, mint mondjuk a vállalkozók által elkövetett büncselekményeknek.

Cope (2011) korábbi szociálpszichológiai kutatásokat összegezve arra a következtetésre jutott, hogy a kudarcai alapján erőteljesebben, nyersebben ítélünk meg valakit, mint azt a valóság indokolná. A stigma, egyszerűen megfogalmazva, egyfajta szégyenfolt a személyen, amely negatívan hat a róla kialakult képre és a hírnevére (Cotterill, 2012; Wiesenfeld et al., 2008), valamint a vállalkozók vonatkozásában negatívan hathat a későbbi vállalkozásalapítási hajlandóságra is (Cope, 2011; Simmons et al., 2014; Singh et al., 2015), mely hatás országonként jelentősen eltérhet (Simmons et al., 2014). mációk alapján akarjuk Magyarországot elhelyezni ebben a modellben, akkor a korábban ismertetett adatok alapján elmondhatjuk, hogy a vállalkozókkal kapcsolatban inkább a negatív attitűdök jellemzőek hazánkban. Az EU-ban a megkérdezettek 82 százaléka adna egy második esélyt azon vállalkozóknak, akik elbuktak, több országban ez az érték a 90 százalékot is meghaladja. Magyarországon a megkérdezettek 69 százaléka adna második esélyt e vállalkozóknak, ami európai szinten a második, míg világviszonylatban a harmadik legalacsonyabb érték (European Commission, 2012). Ezen adatok alapján az a sejtés fogalmazható meg, hogy a stigmatizáció és a negatív attitüdök szintje dimenzió mentén Magyarország inkább a magas kategóriába tartozik. A korábban ismertetett GEM felmérések és Szerb - Kocsis-Kisantal szerzőpáros (2008) kutatása alapján, Magyarországon alacsony a vállalkozók kudarcairól elérhető információk szintje, még ha a hírek többsége negatív is, így lényegében a vállalkozók kezében van ennek a kontrollálása.

Az eddigiekben inkább a Corrigan és szerzőtársai (2010) szerinti társadalmi stigmát mutattam be, mely az ö definíciójuk szerint: egy elöítélet és diszkrimináció, amit a lakosság szélesebb köre támogat, mint sztereotípia. Azonban elkülönítették az önstigmatizációt, mely a társadalmi vélekedés internalizálása, azaz a stigmatizált személy saját magáról alkotott képét is a többiek által elfogadotthoz igazítja, mely fogalomnak a következőkben bemutatott szemléletmódok elméletében lesz jelentős szerepe.

\section{A kudarcot vallott vállalkozók stigmatizációja és válaszreakciókat befolyásoló tényezők csoportosítása}

\begin{tabular}{|c|c|c|c|}
\hline \multirow{2}{*}{$\begin{array}{l}\text { Negatív kulturális } \\
\text { attitűdök elterjedtségének } \\
\text { a szintje, a kudarcot } \\
\text { vallott vállalkozókkal } \\
\text { kapcsolatban (az üzleti } \\
\text { kudarc stigmája). }\end{array}$} & 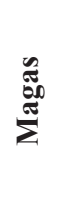 & $\begin{array}{l}\text { - Korlátozott mértékủ kontrollal bír a } \\
\text { vállalkozó a kudarc nyilvánosságával } \\
\text { kapcsolatban. } \\
\text { - Fennáll a stigmatizáció kockázata, de } \\
\text { elkerülhető a kudarc nyilvánosságra jutása. }\end{array}$ & $\begin{array}{l}\text { - Az emberek nem megbocsájtóak a bukott } \\
\text { vállalkozókkal szemben és illegális } \\
\text { tevékenységgel azonosítják a kilépést. } \\
\text { - A vállalkozók hajlamosak lesznek elhagyni } \\
\text { a vállalkozói szférát. }\end{array}$ \\
\hline & 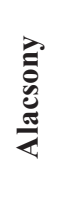 & $\begin{array}{l}\text { - A stigmatizáció szankciói nem súlyosak, } \\
\text { így a vállalkozók könnyebben a vállalkozói } \\
\text { szférába maradhatnak. } \\
\text { - A vállalkozók a kudarcra, mint „tisztelet } \\
\text { jelvényre” tekinthetnek. }\end{array}$ & $\begin{array}{l}\text { - A vállalkozói kudarcokról széles körben } \\
\text { elérhető az információ, de a stigmatizáció } \\
\text { nem jelentős. } \\
\text { - Bizonyos aspektusait a kudarcélménynek } \\
\text { pozitívan is értékelhetik. }\end{array}$ \\
\hline & & Alacsony & Magas \\
\hline
\end{tabular}

Forrás: Simmons és kutatótársai (2014, p. 489.) alapján saját szerkesztés

Simmons és szerzőtársai (2014) létrehoztak egy kétdimenziós modellt, mely alkalmas a vállalkozók reakcióinak elörejelzésére és tipizálására a környezet dimenziónkénti értékelése alapján (alacsony vagy magas), mely az 1. ábrán látható. A modell tartalmazza egyrészt az érzékelt kontrollt a kudarc láthatósága felett, valamint a kudarcot vallott vállalkozókat érő negatív attitüdöknek az elterjedtségét, azaz a stigmatizáció szintjét. Ha a szekunder infor-

\section{A vállalkozói attitűdök}

A Bolton - Lane (2012) szerzőpáros több kutatásában a vállalkozói attitűdöket vizsgálta, mert azt vallották, hogy ezek megváltoztathatók a külső hatásoknak való kitettség függvényében, legyenek akár pozitívak vagy negatívak e hatások. Kutatásomba igyekeztem én is olyan elméleteket integrálni, melyek szerintem az attitüdök körébe tartoznak, azaz megváltoztathatók, hiszen a kutatás jövőbeni 
gyakorlati hasznosítása szempontjából ez lényeges kritérium. Így a tanulmányban a következőkben bemutatott három elméletre (szemléletmódok, kontrollhely, időperspektívák) együttesen használtam a vállalkozói attitüdök kifejezést.

Dweck (2015) elméletében két alapvetően különböző szemléletmód van, a rögzült és a fejlődési. A rögzült szemléletmód azt a meggyőződést takarja, hogy a tulajdonságaink megváltoztathatatlanok. Ez esetben életünk minden helyzete egy megmérettetés, ahol eldől, hogy intelligensek vagyunk-e, vagy sem, alkalmasak vagyunk-e a feladatra, vagy sem. Ezzel szemben a fejlödési szemléletmóddal gondolkodók meggyőződése, hogy az alapvető emberi tulajdonságaink kellő erőfeszítéssel fejleszthetők. A két szemléletmódban a kudarc fogalma is eltérö. A rögzült szemléletmód szerint, ha valami nem sikerül az kudarc, és azt jelzi, hogy nem vagyunk elég tehetségesek vagy épp intelligensek, azaz egy eseményböl (pl.: kudarcot vallottam) tulajdonság lesz (alkalmatlan vagyok a feladatra). Míg a fejlődési szemléletmód szerint csak akkor bukunk el, ha nem vagyunk képesek fejlődni, ha nem használjuk ki a bennünk rejlő lehetőségeket, vagy ha nem teszünk meg mindent a céljainkért. Fontos azonban hangsúlyozni, hogy a kudarc a fejlődési szemléletmódúak számára is lehet fájdalmas, de személyiségüket nem ez határozza meg, ez csak egy megoldandó probléma, amiből tanulni lehet (Dweck, 2015). A szemléletmódokhoz kapcsolódó fogalom a korábban bemutatott önstigmatizáció, mely azt a folyamatot takarja, amikor a vállalkozók a külső vélekedést (például: stimgatizációt) internalizálva alkalmatlannak látják magukat, mint vállalkozó (Simmons et al., 2014). Ráadásul a vállalkozók az őket ért társadalmi stigmát hajlamosabbak lehetnek kivetíteni magukra, mivel az identitásuk gyakran összefonódik a vállalkozásukkal és annak eredményével (Corrigan et al., 2010; Singh et al., 2015; Shepherd et al., 2009).

Az emberek hajlamosak a sikereiket a kiváló képességeiknek, cselekedeteiknek tulajdonítani, míg a kudarcaikat a balszerencsés külső körülményeknek, és ez alól a vállalkozók se kivételek (Basgall, 1988; Cotterill, 2012; McGrath, 1999). Azon vállalkozók esetében pedig, akik még nem tapasztalták meg a kudarcot, még inkább jellemzö, hogy a sikereiket a saját döntéseiknek, cselekedeteiknek tulajdonítják (McGrath, 1999; Ucbasaran et al., 2010). Többek között e gondolatok is indokolták Rotter (1966) kontrollhely elméletének beemelését a kutatásba, melyben két típus különül el, a belső és a külső kontrollos személyeké. Amikor valaki úgy észleli, hogy az események következményei nem teljesen a saját cselekedeteitől függenek, akkor hajlamos úgy tekinteni erre, hogy a szerencse, a véletlen, a sors, a befolyásos személyek, vagy épp a kiszámíthatatlanság miatt következett be, vagyis az őt körülvevő komplex erők miatt. Arra, aki így értékel egy eseményt, használta Rotter a külső kontrollos jelzőt. Azonban, ha egy személy úgy tartja, hogy az események az ő viselkedésétől vagy viszonylag tartós jellemvonásaitól függenek, akkor belső kontrollos személynek nevezzük (Rotter, 1966). A külső kontrollos dimenziót későbbiekben kétfelé bontották, szerencsére és befolyásos személyekre (Levenson, 1974; Kaufmann - Welsh, 1995), így a fogalom hitelessége jelentősen javult (Boydston et al., 2000), ezért is használtam kutatásom során a háromdimenziós kontrollhely elméletet.

Zimbardo és Boyd (2012, p. 82.) szerzőpáros szerint „az idöperspektíva az a gyakran nem tudatos attitüd, ahogyan mindnyájan az időhöz viszonyulunk, illetve az a folyamat, amelynek révén létünket állandóan időkategóriákba illesztjük, hogy ezáltal is rendet, koherenciát és értelmet vigyünk az életünkbe". Zimbardo és Boyd (1999) eredetileg öt dimenzióval alkották meg az elméletüket és kérdőívüket, majd később kiegészítették a transzcendentális jövővel és a holisztikus jelennel, mely utóbbi kettő jelen kutatás szempontjából kevésbé releváns. A (1) múltpozitív és a (2) múltnegatív időperspektívák nevük ellenére nem azt jelentik, hogy csak a múltbeli jó vagy rossz dolgokat idézzük fel, sokkal inkább egy attitüdöt, hogy miként szemléljük a múltunk eseményeit függetlenül annak mibenlététől, melynek sokszor nagyobb hatása van, mint magának az eseménynek. A (3) jelenfatalisták hitvilágának középpontjában gyakran a predesztináció áll, azaz, hogy minden előre elrendezett, így független az egyén tetteitől az életének alakulása, ezért kiszolgáltatottnak érzik magukat. (4) Jelenhedonisták azok, akik folyamatosan keresik az azonnali örömforrásokat, izgalmas helyzeteket és embereket, kevésbé törődve tetteik következményeivel. Míg a (5) jövőorientált személyek gyakran lemondanak vágyaik azonnali kiéléséről a jövőbeli jelentősebbnek vélt hasznok érdekében. Életüket rendszerezetten élik, mindig számolva jelenbeli döntéseiknek jövőbeli költségeivel, azaz „ha-akkor” világban élnek. Feltételezésem szerint a múltpozitív és múltnegatív időperspektívák a gyászfeldolgozás hosszát befolyásolhatják, míg a jövőorientáltság segítheti a vállalkozót, hogy konstruktívan tudjon hozzáállni a kudarchoz, hiszen, mint Zimbardo és Boyd (1999) is említik, stresszhelyzetben a jövőorientáltság erős kapcsolatban van a problémamegoldással.

\section{A kudarcra adott reakciók}

Shepherd és kutatótársai (2009) hangsúlyozzák a kudarcból történő felépülés fontosságát, hiszen ha a vállalkozókra nem egy „egy-üzletes-próbálkozóként” tekintünk, akkor a megfelelö felépülés hozzájárulhat ahhoz, hogy tapasztalt sorozatvállalkozókká válhassanak.

Első lehetséges válaszreakció valójában megelőzi a kudarceseményt, azonban annak előrelátása váltja ki azt. Ez pedig a kudarc késleltetése, mely elsőre kissé irracionálisnak tünő jelenség, mivel pénzügyi szempontból általában rendkívül költséges. Shepherd és kutatótársai (2009) vizsgálata alapján ennek a cselekedetnek három fó oka lehet. (1) A vállalkozó megtagadja a kudarc tényét, hogy igazolja korábbi döntései helyességét, (2) a vállalkozás halálának beismerésével elvesztegetve érezné az eddig befektetett erőforrásokat (pénz, idő, energia), (3) az emberek hajlamosak a későbbi bizonytalan veszteséget választani (kudarc halogatása), még ha az költségesebb is lehet, mint a jelenlegi biztos veszteség (vállalkozás bezárása). Egy más megközelítésben, minél nagyobbak a várt negatív érzelmek, annál valószínűbb a tevékenység halogatása is, 
a negatív érzelmek erejét a visszafordíthatatlan döntések pedig erőteljesen növelik (Anderson, 2003), mint például egy vállalkozás végleges megszüntetése. Shepherd és kutatótársai (2009) szerint a gyász egy olyan érzelmi reakció, ami valami fontosnak az elvesztésekor keletkezik, míg az elözetes gyász már a veszteség elött jelentkezik. Az előzetes gyász azért fontos szerintük, mert felkészíti az egyént a bekövetkező veszteségre, érzelmileg megkezdheti az eltávolodást (esetünkben a vállalkozástól), csökkenti a később jelentkező hagyományos értelemben vett gyászt (így a kudarc érzelmi költségeit is) és segít feldolgozni a veszteséget, mert így az az előre jelzett folyamat részét fogja képezni. Ez alapján, még ha nem is tudatos és anyagilag megterhelö, de egy jó döntés lehet a kudarc késleltetése, hiszen segíthet kiegyensúlyozni a kudarc pénzügyi és érzelmi költségeit az optimális felépülés érdekében (Shepherd et al., 2009).

Sokan összehasonlítják egy szerettünk elvesztését azzal, amikor a vállalkozásunkat veszítjük el. Természetesen a hasonlóság ellenére a két fajta gyász jelentős eltérésekkel is rendelkezik, például szerettünk elvesztéséből inkább filozófiai és egzisztenciális értelemben tanulunk, míg egy vállalkozás elvesztése esetén inkább gyakorlati és konstruktív szempontok dominálnak (Shepherd, 2003). Különféle tényezők felerösíthetik a gyász érzetét, például több egymást követő üzleti kudarc halmozódása, erőteljesebb kötődés az elvesztett vállalkozás és a vállalkozó között (Shepherd et al., 2009), valamint a Cope (2011) megfigyelései alapján a nők esetében is erőteljesebb érzelmek társulnak egy vállalkozás elvesztéséhez, mint az a férfiaknál tapasztalható.

Shepherd 2003-as kutatásában fogalmazta meg a gyász feldolgozásának két lehetséges módját, a veszteségorientációt (loss orientation) és a helyreállítás-orientációt (restoration orientation). A veszteségorientáció egy aktív szembefordulást jelent a veszteséggel és az ehhez társuló negatív érzelmekkel (például beszélgetés a vállalkozás elvesztéséről), amely érzelmileg igen kimerítő tud lenni. A helyreállitás-orientációnak két meghatározó része van, az egyik egy elkerülő mechanizmus, amikor is a vállalkozó igyekszik elvonni a figyelmét a vállalkozás elvesztéséröl, a másik pedig egy proaktív megközelítés, amikor egyéb tevékenységekkel, másodlagos stresszforrásokkal tereli el figyelmét a veszteségről (ami lehet akár egy új vállalkozás alapítása vagy egy új hobbi). A helyreállítás-orientáció esetén azonban nagy a veszélye, hogy újra ugyanazokat a hibákat követi el a vállalkozó egy új vállalkozásban, mivel nem volt ideje feldolgozni és tanulni az előző kudarcból. Shepherd (2003) a két megküzdési mechanizmus közötti oszcillációt javasolja, amely jelentősen gyorsítja a feldolgozási folyamatot, ahhoz képest mintha csak az egyiket használnánk, mivel mindkettő előnyeit ki tudja használni, viszont egyikben sincs túl sok ideig a vállalkozó, így a negatív hatásaikat minimalizálni tudja. Cope (2011) azzal egészítette ki, hogy hatékonyabb, ha először a veszteségorientációt alkalmazza a vállalkozó a gyász leküzdésére, mivel így enyhül a kudarc okozta zavaró fájdalom és trauma.
A kudarcból történö tanuláshoz először fel kell épülnie a gyászból a vállalkozónak (Shepherd, 2003; Shepherd et al., 2009). Több kutató is egyetért abban, hogy a kudarcainkból többet tanulhatunk, mint sikereinkből, mivel ilyenkor egyedi tudásra tehetünk szert (McGrath, 1999; Sitkin, 1992), új mintákat tanulhatunk meg, szabadabban gondolkodhatunk új ötleteken. Sitkin (1992) meg is fogalmazta, hogy a siker előnyeit gyakran vizsgálták már a kutatók és jól le is írták, azonban a siker hátrányait nem igazán, hiszen, ha minden jól megy, akkor jellemzően nem keresünk új utakat, hatékonyabb megoldásokat (,,ami nem romlott el, azt nem kell megjavítani”). Továbbá Sitkin (1992) szerint a kudarc egyik nagy haszna lehet a tanulási folyamatban, hogy könnyebb azonosítani, miért történt a kudarc, mint azt, hogy miért lett sikeres egy vállalkozás, így a kudarcelemzés egy kiemelt eszköz lehet a bizonytalanság csökkentésében. A kutatók között nagy az egyetértés abban, hogy a kudarc során tanultakat a vállalkozók jelentős része egy új vállalkozás alapításánál használja fel (Cope, 2011; Shepherd, 2003; Shepherd et al., 2009; Singh et al., 2015; Ucbasaran et al., 2013). A vállalkozók kudarcból történő tanulása akkor jöhet létre, ha rendelkeznek a kudarc okaira vonatkozó információkkal, így képesek felülvizsgálni az eddigi tudásukat, hiedelmeiket, döntéseiket és tevékenységeiket, hogy ezt követően hatékonyabban tudják irányítani a jövőbeli vállalkozásaikat (Shepherd, 2003). A kudarcból történő tanulást a gyászhoz kapcsoló negatív érzelmeken túl (Shepherd, 2003; Shepherd et al., 2009), többek között akadályozhatja a rögzült szemléletmódú gondolkodás is, hiszen a tulajdonságok, amelyekre így gondolnak a vállalkozók, azokat meg se próbálják fejleszteni, mert hitviláguk szerint ez nem lehetséges (Dweck, 2015). Jelentősebb stresszhelyzet esetén, mint amilyen a kudarc is, a jelenfatalista gondolkodás ellenállást jelenthet a problémamegoldó folyamatokkal kapcsolatban, valamint a jelenhedonista időperspektíva elkerülő reakciókat válthat ki az egyénből. Mindkét esetben a tanulás nem, vagy igen korlátozottan történhet meg (Zimbardo - Boyd, 1999). Kizárólag külső tényezők megjelölése a kudarc okaiként is megakadályozhatja a tanulást, hiszen ily módon hajlamosabb lehet a vállalkozó nem átgondolni, hogy legközelebb mit csinálhatna jobban.

Sitkin (1992) alkotta meg az intelligens bukások fogalmát, mely tömören, olyan kicsi és relatíve ártalmatlan bukásokat takarnak, melyek a leghatékonyabbak a tanulás serkentésében. Azonban Sitkin szerint, azon kudarcok, melyek mélyen próbára teszik az egyén hiedelmeit, kevésbé vezetnek tanuláshoz, mivel nehéz kezelni az ilyen szinten fenyegető tapasztalatokat. Az intelligens bukások (1) előre jól eltervezett cselekedetek, (2) kimenetelük bizonytalan, (3) csekély mértékủek, (4) gyors ciklusban adnak visszacsatolást, valamint (5) relevánsak a személy vagy vállalat szempontjából. Úgy gondolom a vállalkozói kudarcok vonatkozásában csak a kevésbé jelentőseknél vagy portfólióvállalkozóknál értelmezhető, hiszen ott érvényesülhet csak a csekély mértékü feltétel. 


\section{A módszertan és a minta ismertetése}

A kutatás elméleti alapja három fő modulra osztható (1) a kudarc folyamatára, beleértve az erre adott vállalkozói reakciókat, valamint e folyamatra ható tényezőkre úgy, mint (2) a vállalkozók attitüdjei és (3) a környezeti hatások. E hármasság elkülönülését, az alájuk tartozó főbb elméleteket és az egyes területek közti egyszerüsített kapcsolatokat a 2. ábrán jelenítettem meg.

zói tapasztalatát és a korábbi vállalkozásaikból történő kilépés okait. Ezután végigmentünk a megkérdezettek legjelentősebbnek vélt kudarcának folyamatán, a kudarc késleltetésétől és az előzetes gyásztól (Shepherd et al., 2009), a kudarckori vállalkozói státuszon keresztül (Shepherd et al., 2009; Ucbasaran et al., 2010), a kudarc következményeiig, költségeiig (Cope, 2011). A következő nagy blokk a kudarcra adott reakciók voltak, beleértve a gyászt és a gyász feldolgozásának két orientációját (Cope, 2011; Shepherd, 2. ábra 2003), valamint a kuA vállalkozói kudarc folyamata és az erre ható tényezők egyszerűsített modellje darcból történő tanulást (Cope, 2011; Cotterill, 2012; Shepherd et al., 2009; Sitkin, 1992). A gyász mértékének értékeléséhez Shepherd (2003) tanulmányában javasolt Hogan és kutatótársai (2001) által empirikusan kialakított úgynevezett Hogan gyászreakció ellenőrzőlistát (Hogan Grief Reaction Checklist HGRC) használtam. A stigmatizációra vonatkozó kérdéseket úgy tettem fel, hogy pozitív kimenetele is lehessen a válasznak (például: tapasztaltabbnak ítélték meg a vállalkozót a kudarcot követően), valamint el tudjam helyezni az egyes vállalkozókat a korábban bemutatott Simmons és kutatótársai (2014) által kifejlesztett kétdimen-

A kutatás feltáró jellegéből fakadóan, a primer részhez kvalitatív módszert választottam, azaz interjúkat készítettem vállalkozókkal 2016 őszén, mely döntést megerősítette, hogy a nagy elemszámú kutatást eleve korlátozta a kudarcot átélt vállalkozók hozzáférhetősége. Az interjúfonál kérdéseit a szakirodalomban fellelhető kérdőívek segítségével fogalmaztam meg, és az időperspektívák ötdimenziós modelljét célszerűségi okokból kérdőívvel vizsgáltam, melyet az interjúalanyokkal az interjú megkezdése előtt töltettem ki. Az időperspektívák felmérésére használt kérdőív Orosz és kutatótársai (2015) által magyar mintán validált rövidített 17 elemes változata volt. Az interjút a vállalkozók általános megítélésével, valamint a demográfiai blokkal kezdtem, ahol felmértem az interjúalanyaim vállalkoziós modellben. A záró blokkban a vállalkozói attitüdöket vizsgáltam. A kontrollhely esetében Sapp - Harrod (1993)

Forrás: saját szerkesztés

\section{IDÖPERSPEKTÍVÁK}

háromdimenziós (belső kontroll, szerencse és befolyásos személyek) kérdőíve alapján fogalmaztam meg az interjúk során használt kérdést, míg a szemléletmódok vonatkozásában Dweck (2015) könyvének magyar fordításában szereplö mintakérdéseket vettem alapul.

A tesztinterjú és az ezt követő korrekciók után elkezdtem a kudarcot átélt vállalkozók felkeresését és megkérdezését. Hólabda-mintavétellel végül 8 kudarcot átélt vállalkozóval készítettem interjút. Fontos, hogy mindegyikükhöz ajánlás vagy személyes ismeretség révén jutottam el, így voltak hajlandók őszintén nyilatkozni egy ilyen kellemetlen témáról. Singh és kutatótársai (2015) kiemelték, hogy olyan vállalkozókat szinte lehetetlen közvetlenül elérni, akik nem jutottak túl a traumán. Megkérdezésükre én is kísérletet tettem, 
azonban még közvetetten pszichológuson keresztül se sikerült elérnem ilyen alanyokat, pedig hasznos plusz információkhoz juthattam volna. Végül a 8 interjúról, megközelítőleg 6 órányi hangfelvétel készült. A feldolgozáshoz a megalapozott elmélet (grounded theory) elveit alapul véve (Charmaz, 2006), először kódokkal láttam el minden egyes interjúról készült hangfájl releváns részeit, mely végül több mint 400 különböző kódot eredményezett. Ezt követően e kódokat soroltam be különféle fö-, illetve alcsoportokba, melyek megkönynyítették az eredmények értékelését, még ha esetenként többször felül is kellett vizsgálnom a csoportokat, új kategória bevezetése vagy a jelenséget jobban leíró mintázat felismerése miatt. Ahol megvolt az elemzési módszertan, ott igyekeztem a meglévő kategóriákat alkalmazni, például a gyász esetén a HGRC-t (Hogan et al., 2001), vagy a kudarc költségeinél Cope (2011) kategóriáit, még ha az eredeti kategóriák bővítésre is szorultak egyes helyzetekben.

A mintába került 8 vállalkozó eddig összesen 30 vállalkozás irányításában vett részt, 23 kudarcot élt át és átlagos vállalkozói tapasztalatuk 13 év volt a megkérdezéskor. A mintámba került legnagyobb kudarc egy több mint egymilliárdos árbevételü és 120 alkalmazottat foglalkoztató vállalkozáshoz kapcsolódott. Az is megfigyelhető, hogy a megkérdezettek két hullámban kezdtek vállalkozni, egyrészt a karrierjük elején (19-25 éves korukban), vagy már 10-15 év alkalmazotti tapasztalat után (34-38 évesen), mely csoportosulás valószínúleg a hólabda-mintavételből fakadhatott.

\section{A kutatás eredményei}

Az eredmények ismertetésekor részben más logikai ívet követtem, mint a szakirodalmi áttekintés során, mivel itt hangsúlyosabb az időbeli egymásra épülés, valamint egyes szempontok bemutatása előtt fontos megismerni magának a kudarcnak a folyamatát és az erre adott vállalkozói reakciókat. Így a következő sorrendet alkalmaztam: először végigmentem a kudarc folyamatán az előzményektől, a kudarc körülményein át, a következményekig. Ezt követően kitértem a gyászra és ennek leküzdésére, a környezeti hatásokra, a vállalkozói attitüdökre, valamint a levont tanulságokra. Zárásként pedig a tanulmány címében feltett kérdésre adtam választ.

A kudarcot megelőzö időszakot vizsgálva, a mintámban csupán egy vállalkozónál jelent meg a kudarc késleltetésének motívuma. Három megkérdezett esetén enyhe elözetes gyász volt megfigyelhető, azaz a Hogan és kutatótársai (2001) által megalkotott HGRC szerinti 6 kategóriából (kétségbeesés, pánik, személyes növekedés, vád és harag, leválás, valamint szervezetlenség) legalább két helyen jelentkeztek érzelmek. A leggyakoribb szinte mindenkinél jelentkező érzelemcsoport a kétségbeesés volt. Ketten nem csak érzelmileg kezdtek felkészülni a kudarcra, a vállalkozás elengedésére, hanem cselekedtek is az optimális kilépés elérése érdekében.

A kudarc körülményeihez tartozik, hogy három vállalkozó rendelkezett portfólióval a kudarc bekövetkezésekor, azaz aktív szerepe volt másik vállalkozás irányításában vagy alkalmazottként is dolgozott, így jövedelmileg és érzelmileg kevésbé voltak kiszolgáltatva az elvesztett vállalkozásnak. A 8 vállalkozó 23 kudarca kapcsán a vállalkozásból történő kilépés fő okai elsősorban belső problémák voltak, azon belül is a személyes hibák (például: „túlzott optimizmus"), az üzlettársakkal kapcsolatos problémák (például: „hatalmi játszmák”), valamint az eredményesség hiánya (például: „feleződő forgalom az utolsó 5 évben"). Három vállalkozót leszámítva, minden esetben többen irányították a céget, ami valamilyen szintű felelősségmegosztást is jelentett, azonban ha hozzávesszük azt, hogy a második leggyakoribb kilépési ok az üzlettárs kapcsán jelentkező problémáknak volt tulajdonítható, akkor ez már lehet esetükben inkább hátrány volt, mint előny.

A kudarc következményeit, költségeit vizsgálva csupán az interjúalanyaim fele számolt be jelentősebb negatív következményről, legyen az pénzügyi (például: „minden megtakarítását elvesztette a család”), társadalmi (például: „szűkülő baráti kör”), vállalkozói (például: „,csökkenő vállalkozási hajlandóság”) vagy szakmai következmény (például: nem akartak a kudarcot vallott vállalkozóval együttmüködni). Cope (2011) a kudarc költségeiröl szóló hatkategóriás csoportosítását egy plusz elemmel bővítettem, a jogi következményekkel, mivel az 3 vállalkozó esetén is jelentős területnek bizonyult (például: ,5-6 éves bírósági ügy").

Valahol a kudarc következménye, de mégis inkább már a vállalkozó reakciója a gyász. A már szinte klisévé vált kijelentés, hogy a vállalkozók úgy tekintenek a vállalkozásukra, mint a gyerekükre, két interjúalanynál is szóba jött és ez erősíthette a gyász érzetét. A gyász mértéke igen változatos volt a megkérdezettek között (HGRC alapján értékelve), kettejüknek elhanyagolható, hárman közepes erősségü, míg másik hárman erőteljes gyásszal kellett, hogy megbirkózzanak a kudarcot követően. A gyász mértéke és a használt feldolgozási orientáció (veszteség- és helyreállítás-orientáció) között nem tapasztaltam összefüggést. A legerőteljesebb gyásszal rendelkező vállalkozó csupán részben alkalmazta a két orientációt, azonban a kettő közötti oszcilláció segítségével így is felépült a gyászból. Összességében a gyász kapcsán elmondható a szakirodalom és az interjúk alapján, hogy a gyász mértékét többek között erősitheti a vállalkozás müködtetésének időtartama, a kudarc pénzügyi mérete, a környezetből érkező stigmatizáció, a vállalkozások elvesztésének sorozata rövid időn belül, vagy épp az erőteljes múltnegativitás. A halmozódó kudarcok gyászerősítő hatására jó példa az egyik megkérdezettem, akinél a legjelentősebb kudarca előtti két évben hullott szét az addig gondosan felépített négy vállalkozásból álló portfóliója, és nála valóban a második legerősebb gyászt figyelhettem meg, így a felépüléshez erőteljesebben kellett alkalmaznia a gyászfeldolgozó orientációk mindkét formáját. Azonban vannak olyan tényezők is melyek mérsékelni tudják a gyász érzetét, például ha a vállalkozó erőteljesen a jövőbe tekint, azaz jövőorientált, ha kevesebb negatív következménye van a kudarcnak, vagy, ha a kilépéskor a vállalkozó rendelkezésére áll egy portfólió, így nem csak anyagilag, de érzelmileg is több lábon áll. 
A vállalkozók megitélése kapcsán több interjúalanyom is visszakérdezett, hogy a jelenbeli vagy múltbeli helyzetről beszéljen, mert szerintük egy átmeneti időszakban vagyunk, mely azt sejteti, hogy nem feltétlenül tekinthető rögzült állapotnak az a negatív kép, amire a szekunder források alapján következtettem. Négy vállalkozó, akinél egyértelmüen elkülönült a múltbeli megítélés a jelentől, ott kizárólag negatív jelzőket használtak arra vonatkozóan, hogy mit tapasztaltak a vállalkozók megítéléséröl a környezetükben a múltban. A jelenbeli helyzetről beszélgetve, azonban azt tapasztaltam, hogy hárman továbbra is úgy érzik, negatív a vállalkozók társadalmi megítélése, míg hármuk szerint mostanra pozitívra változott az emberek képe a vállalkozókról (két interjúalany esetében nem volt egyértelműen eldönthető). Tehát a megkérdezett vállalkozók nem érezték annyira negatívnak a megítélésüket, mint arra a szekunder információk alapján következtettem.

Volt azonban, amiben teljes egyetértés volt a szekunder információk és az interjúalanyaim között, ez pedig a vállalkozók kudarcaira vonatkozó információk elérhetösége és kontrollálhatósága. A szekunder források alapján, mint írtam, a médiában kevés a vállalkozók kudarcaira vonatkozó elérhető információ. Ezt az interjúalanyaim is megerősítették, annyi kiegészítéssel, hogy nyilván a legális, jogi következményei a megfelelö helyeken elérhetőek (például: e-cégjegyzék, e-beszámoló), viszont ezekből csak a kudarc objektív része, sőt annak is csak egy szelete ismerhető meg, ami a valós körülményekről nem sokat árul el. Ráadásul mivel a média nem fordít erre jelentős figyelmet, így könnyen kontrollálhatják a vállalkozók, hogy mit osztanak meg a kudarcaikra vonatkozóan. Ketten azonban felvetették a kérdést, hogy biztos jó ez így? Hiszen így a levont tanulságokat sem osztják meg, pedig sok kezdő vállalkozó tanulhatna ezekből és nem csak a külföldi „szürke irodalomban” (blogok, cikkek) kéne ilyen információk után kutakodniuk.

Az előző két bekezdésben részletezettek alapján, két vállalkozót leszámítva, be tudtam sorolni minden egyes vállalkozót Simmons és szerzőtársai (2014) modelljébe. Kettejük esetében csak azt lehetett teljes biztossággal megállapítani, hogy a kudarcokra vonatkozó információkat képesek a vállalkozók kontrollálni, és így ezen információk láthatóságának a foka náluk is alacsony, stigmatizációként, negatív attitüdök vonatkozásában, vonatkozásában azonban nem tudtam egyértelműen elhelyezni őket. Összességében Magyarországon a kudarcokra vonatkozó információk láthatóságának foka alacsony mind a szekunder, mind a primer adatok alapján, azonban a negatív attitüdök, a stigmatizáció terén vegyes képet kapunk. Ezek alapján általánosságban az érzelemközpontú helyett, a problémamegoldó stigmamenedzsment-stratégiák lehetnek célszerűek, azaz a vállalkozók aktívan alakíthatják a stigmát vagy a helyzeteket, melyben kialakulhatna az (Simmons et al., 2014). Magas stigmatizációs szint és alacsony szintü információnyilvánosság esetén a vállalkozók hajlamosabbak társas vállalkozást indítani, vagy csak később indítani új vállalkozást azért (Simmons et al. 2014), hogy a kudarc feledésbe merüljön (Wiesenfeld et al., 2008).
Az is kérdéses, hogy az egyes vállalkozók a legjelentősebb kudarcuk kapcsán tapasztaltak-e változást a megítélésükben, akár negatívan (stigmatizáció), akár pozitívan. Az alanyok fele nem tapasztalt eltérést a megítélésükben a kudarcot követően, míg hárman negatív változást tapasztaltak, van, akit a családjában is „bukott vállalkozóként” bélyegeztek meg. Míg egyikük kettős változást tapasztalt, egyrészt föként a vállalkozók részéről „,kárörömben” volt része, addig mások a segítségére siettek mind lelki, mind továbblépési ötletek terén.

A következő kérdéskörben, hogy a vizsgált vállalkozói attitüdök miként kapcsolódnak a kudarcfeldolgozáshoz, elsőként a szemléletmódokat mutatom be. A megkérdezett vállalkozók közül (1) négyen mind a tulajdonságaikra, képességeikre, mind az alapvető személyiségjegyeikre fejleszthetőként, azaz növekedési szemléletmóddal tekintettek, míg (2) a másik fele az interjúalanyaimnak az alapvető személyiségjegyeire rögzültként tekintett és (3) egy olyan vállalkozó se volt, aki a vállalkozáshoz szükséges tulajdonságokra, képességekre is rögzültként, nem igazán fejleszthetőként tekintett volna. A részben rögzült szemléletmóddal rendelkező vállalkozók (2) esetében nagyobb hatást gyakorolhat rájuk a környezet stigmatizációja. Náluk nagyobb hajlam feltételezhető az önstigmatizációra, azaz a környezetükben levő vélekedések könnyebb elfogadására, például, hogy ők alkalmatlanok egy vállalkozás vezetésére.

A kontrollhely vonatkozásában egyértelmüen a belső kontrollosság volt jellemző a megkérdezettekre, azaz abban hittek, hogy elsődlegesen tetteik és képességeik vannak hatással az életük alakulására és kizárólag egy interjúalanyomnál volt más a helyzet. A belső kontrollosságot jól megragadták a következő, interjúk során elhangzott mondatok: „,szerencsét csak a megfelelő képességek meglétével tudjuk kihasználni”, vagy „,a jó vállalkozó bármilyen környezetben képes vállalkozni”. Az elsődlegesen a befolyásos személyek és a hatalom hatásában hívő, külső kontrollos vállalkozó élte át a legjelentősebb léptékü kudarcot, ráadásul azt egy erőteljes külső hatás váltotta ki. A kudarc egyik tanulságát úgy fogalmazta meg, hogy ,,jelenleg Magyarországon bárkivel, bármit meg lehet csinálni". Másrészt, említést tett arról, hogy ő régen hitt abban, hogy a saját tettei befolyásolják a vállalkozásának és életének az alakulását, de mára már kevésbé hisz ebben, mely mondat jól tükrözi, hogy egy kellően nagy kudarc képes megváltoztatni a vállalkozó elsődleges kontrollhelyét.

Az időperspektívákat megvizsgálva egyedül az erőteljes jövőorientáltság volt egységesen jellemző a megkérdezett vállalkozókra, azaz folyamatosan mérlegelik jelenbeli döntéseik jövőbeli következményeit, ami már csak a hivatásukból kifolyólag se meglepő, míg a másik négy időperspektíva vonatkozásában egyedileg ingadoztak az értékek. Így a vállalkozók egyedileg történő részletesebb leírása adhatna további eredményeket, például az egyetlen elsődlegesen külső kontrollban hívő vállalkozó vonatkozásában itt is megjelentek szélső értékek, mégpedig ő rendelkezett a legmagasabb (közel maximális) múltnegatív és jelenfatalista értékekkel, aminek oka szintén lehet az őt ért jelentős kudarc. 
A leggyakoribb levont tanulságok az üzlettársakhoz (például: „nem célszerű üzletet a barátsággal keverni”), az üzleti megfontolások (például: ,nyitottabb üzleti modell”), valamint a személyes tanulságok (például: „,kevésbé kéne hallgatni a véleményvezérekre") témaköreihez kapcsolódtak, melyek jól összecsengenek a főbb kilépési okokkal. Az előbbieken túl a kudarckezelés terén is többen tanultak a vállalkozásaik elvesztése következtében, bár ez föként azoknál jelentkezett, akik több kudarcot is átéltek. Kiemelném, hogy egy vállalkozó semmilyen tanulságot nem vont le a karrierje során, pedig 4 vállalkozást is elvesztett és ő az, akinél lényegében a gyásznak se volt semmilyen jele megfigyelhető az általa elmondottak alapján. Volt azonban három interjúalanyom, akik alapvetően egy tanulási folyamatként tekintenek a vállalkozói létre (például: ,,a vállalkozások a fejlődésről szólnak”), sőt egyikük a kudarc szó hallatán kikérte magának, hogy ez nem kudarc, hanem „tanulási folyamat”.

Kettejük esetében, akik eleve tanulási folyamatként tekintettek a vállalkozói létre beszélhetünk Sitkin (1992) értelmezésében ,,intelligens bukásokról”. Egyikük vállalkozásánál folyamatosan gyüjtötték a visszajelzéseket a piacról, amit előre jól elterveztek és már az elejétől számoltak a kudarccal, tehát az egész tesztjellegü volt számukra. A gyász közepes mértéke alapján a kudarc csekély súlyú volt, és így teljesült az intelligens bukás minden követelménye. A másik vállalkozó esetében inkább vállalkozásai sorozatában beszélhetünk ,intelligens bukásokról”, mert céltudatosan számára egyre érdekesebb vállalkozásokban vett részt, így közelítve az, ,életcélja” felé. E nagyobb célhoz képest az egyes kudarcok is mérsékeltebbnek hatottak, melyet az is megerősít, hogy még a legjelentősebb se váltott ki belőle eröteljes gyászérzetet. Igyekezett minél gyorsabban kideríteni, hogy az egyes vállalkozások működnek-e, kellően vonzóak-e számára vagy sem, ezt jelzi az is, hogy 9 év vállalkozói tapasztalat alatt 5 vállalkozás irányításában vett részt.

Eredményeim zárásaként megválaszolnám a tanulmány címében is feltett kérdést, hogy a kudarc vajon a vállalkozói lét végét vagy egy új kezdetet jelent-e? Ami az interjúalanyaimat illeti, öten jelenleg is vállalkozók, ebből ketten ráadásul portfólióban tevékenykednek. Azonban a három vállalkozói létet elhagyó megkérdezett közül egyikük, aki 4 vállalkozás sorozatos csődje után kényszerült alkalmazotti pályára, már most aktívan keresi a visszautat a vállalkozói szférába. A másik két, az interjú készítésekor alkalmazottként tevékenykedő megkérdezett, az első vállalkozás és az első kudarc után hagyta el a vállalkozói életpályát.

Egy jövőbeni érdekes kutatási irány lehet a kudarcot követő karrierdöntés vizsgálata, azaz hogy miért hagyják el a vállalkozói létet vagy épp miként léptek túl úgy a kudarcon egyes vállalkozók, hogy továbbra is a vállalkozói szférában maradtak. Ezt a kérdéskört Ucbasaran és szerzőtársai (2013) is kiemelték, hiszen ilyenkor nem csak a vállalkozó, de a társadalom is veszíthet. Szerintük egy lehetséges magyarázat a vállalkozói karrierút elhagyására, ha a kudarc - korábban bemutatott - költségei magasabbak, mint a kudarcból történő tanulás hasznai. Egy másik ok lehet a vállalkozói pálya elhagyására, ha az adott kultúrában magas a kudarcot átélt vállalkozók stigmatizációjának szintje és a kudarchoz kapcsolódó információk is széles körben elérhetők (Simmons et al., 2014).

\section{Összegzés}

A kutatásom célja a vállalkozók kudarcra adott reakcióinak és a folyamatra ható tényezőknek a felderítése volt. Ennek érdekében számos elméletből állítottam össze a kutatásom alapját képező interjúfonalat és kérdőívet, mely négy fő területre volt osztható: a kudarc folyamata, a vállalkozói reakciók, a vállalkozói attitüdök és a környezeti hatások. Az alábbiakban kiemeltem a föbb eredményeket, a kutatás értékeit, korlátait és a további kutatási lehetőségeket.

A kutatásban részt vevő vállalkozók erőteljes jövőorientált időperspektívával rendelkeznek és inkább a növekedési szemléletmód jellemzi őket. A vállalkozásból történő kilépés okai főként belső problémák voltak és a vállalkozók fele számolt be jelentősebb negatív következményekről a kudarcuk kapcsán. A kutatásom során egyaránt találtam a gyász mértékét növelö (például: erőteljes múltnegativitás, stigmatizáció) és csökkentő tényezőket (például: rendelkezésre álló portfólió). Még egy relatíve kis elemszámú mintán is sikerült a szakirodalomban több speciális esetként emlegetett jelenséget megismernem, mint a portfólióvállalkozók érzelmi költségeinek a megosztása, vagy a halmozódó üzleti kudarcok hatása a gyász mértékére. Ráadásul volt, akinél olyan jelentős kudarcot vizsgálhattam meg, hogy a saját képességeibe vetett hitét is megingatta, és belső kontrollosból, külső kontrollos személy lett. A vállalkozók megítélése néhány interjúalanyom és a saját véleményem szerint is, egy átmeneti fázisban van, ahol a korábbi negatívból elindult pozitív felé a közvélekedés. Az interjúalanyaim fele tapasztalt stigmatizációt a legjelentősebb kudarcuk kapcsán. Több vállalkozó kiemelte, hogy kevés információ érhető el a vállalkozók kudarcairól, ami nem minden esetben elönyös, mert így a vállalkozók a levont tanulságokat sem osztják meg nyíltan. Csak egy vállalkozó nem vont le tanulságot, míg a többiek igen, sőt hárman eleve tanulási folyamatként tekintenek a vállalkozásra. Öten jelenleg is vállalkozók (ketten portfólióban tevékenykednek) és egy hatodik volt vállalkozó is keresi a visszautat, így azt mondhatom, hogy tartósabban csak ketten hagyták el a vállalkozói szférát a kudarcot követően.

A kutatás legnagyobb hozzáadott értékének tekintem a létrehozott, eddigieknél komplexebb modellt a vállalkozói kudarcok vizsgálatához. A hazai szakirodalomban eddig kevésbé kutatott téma a vállalkozói kudarcfeldolgozás, így reményeim szerint ez a tanulmány új kutatások alapját képezheti. Tovább erősíti a kutatást, hogy a vállalkozói kudarcfeldolgozás folyamatának jobb megismerése fontos és aktuális téma, melyet az interjúalanyaim többsége is megerösített, így hosszú távon akár gyakorlati haszna is lehet.

Azonban, mint minden kutatásnak, ennek is vannak korlátai és úgy gondolom ezekkel jobb tisztában lenni, 
ha megfelelően akarjuk értékelni az eredményeket. A témám igen szerteágazó volt, ami korlátozta a kapcsolódó tudományterületek (például: gyász folyamatának) megfelelő szintű megismerését, de igyekeztem minél alaposabb szakirodalmi kutatást végezni a vállalkozói kudarcfeldolgozás területén, közben nagy hangsúlyt helyezve az elméletek kapcsolódási pontjaira. A másik Singh és kutatótársai (2015) által is megfogalmazott korlát, hogy az interjúk és a kudarcélmény között sokszor több év is eltelt, ami ronthatja az eredmények érvényességét. Emiatt kértem, hogy amennyiben több kudarc is érte a vállalkozókat, úgy a legjelentősebbnek tartottról beszéljenek, lévén erről lesznek valószínüleg a legélénkebb emlékeik. Továbbá, ez az esetenként traumatikus élmény torzíthatja az információkat és így az eredmények megbízhatóságát, mivel hajlamosak vagyunk eltávolítani magunkat a kudarctól (Cotterill, 2012), és akár másra terelni a felelősséget (Basgall, 1988), valamint ezekről eleve nehezebben is beszélünk. Ezek enyhítése miatt volt kiemelten fontos, hogy ismerösi ajánlásokkal keressem meg a kellően nyitott interjúalanyaimat, valamint, hogy minél biztonságosabb légkört próbáljak teremteni az interjú során.

Úgy gondolom, hogy a téma kutatása még rengeteg lehetőséget tartogat a jövőre nézve, többek között specifikus mintákon történő vizsgálódás (például: családi vállalkozók, első vagy halmozódó kudarcot átélők). Jelentős hozzáadott értékü lehet az is, ha a mintába olyan vállalkozók is bekerülnek (akár közvetett módon), akik képtelenek voltak feldolgozni a kudarcélményt (Singh et al., 2015), így a két csoport együttes vizsgálata új szempontokra, tanulságokra világíthatna rá, hogy miért nem sikerül a továbblépés egyes vállalkozóknak, és másoknak pedig igen. Azonban úgy gondolom, mint a legtöbb kutatásnak, ennek is a végső célja a gyakorlati hasznosítás, amely szerintem egy javaslatrendszerben ölthetne testet. Azaz olyan irányelvek, módszerek kidolgozásában, melyek beépíthetők a vállalkozásoktatásba, így segítve a kezdő vállalkozók jobb kudarcfeldolgozását és tanulását a kudarcaikból.

\section{Felhasznált irodalom}

Amorós, J. E. - Bosma, N. (2014): Global Entrepreneurship Monitor 2013 Global Report: Fifteen years of assessing entrepreneurship across the globe. http://www. gemconsortium.org/docs/3106/gem-2013-global-report, Letöltve: 2014. 09. 15.

Anderson, M. C. (2003): Rethinking interference theory: executive control and the mechanisms of forgetting. Journal of Memory and Language, 49, 415-445. o.

Basgall, J. A. - Snyder, C. R. (1988): Excuses in waiting: external locus of control and reactions to success-failure feedback. Journal of Personality and Social Psychology, 54, 4, 656-662. o.

Bolton, D. L. - Lane, M. D. (2012): Individual entrepreneurial orientation: development of a measurement instrument. Education + Training, 54, 2/3, 219-233 o.

Boydston, M. - Hopper, L. - Wright, A. (2000): Locus of control and entrepreneurs in a small town. San Anto- nio, Texas: Association for Small Business and Entrepreneurship

Burke, A. E. - FitzRoy, F. R. - Nolan, M. A. (2008): What makes a die-hard entrepreneur? Beyond the 'employee or entrepreneur' dichotomy. Small Business Economics, 31, 2, 93-115. o.

Cardon, M. S. - Stevens, C. E. - Potter, D. R. (2011): Misfortunes or mistakes?: Cultural sensemaking of entrepreneurial failure. Journal of Business Venturing, 26, 1, 79-92. o.

Cope, J. (2011): Entrepreneurial learning from failure: An interpretative phenomenological analysis. Journal of Business Venturing, 26, 6, 604-623. o.

Charmaz, K. (2006): Constructing grounded theory: A practical guide through qualitative analysis. London: Sage Publications

Corrigan, P. W. - Morris, S. - Larson, J. - Rafacz, J. Wassel, A. - Michaels, P. - Wilkniss, S. - Batia, K. - Rüsch, N. (2010): Self-stigma and coming out about one's mental illness. Journal of Community Psychology, 38, 3, 259-275. o.

Cotterill, K. (2012): A Comparative Study of Entrepreneurs' Attitudes to Failure in Technology Ventures. International Journal of Innovation Science, 4, 2, 101116. 0.

Dweck, C. S. (2015): Szemléletváltás - A siker új pszichológiája. Budapest: HVG Kiadó

European Commission (2012): Entrepreneurship in the EU and beyond (Flash Eurobarometer 354), http://ec.europa.eu/public_opinion/flash/fl_354_en.pdf, Letöltve: 2015. 09. 27.

Gnyawali, D. - Fogel, D. (1994): Environments for Entrepreneurship Development: Key Dimensions and Research Implications. Entrepreneurship: Theory and Practice

Hogan, S. - Greenfield, D. B. - Schmidt, N. L. A. (2001): Development and validation of the Hogan grief reaction checklist. Death studies, 25, 1, 1-32. o.

Kaufmann, P. - Welsh, D. (1995): Locus of control and entrepreneurship in the Russian Republic. Entrepreneurship: Theory and Practice, 20, 43-56. o.

Kelley, D. - Singer, S. - Herrington, M. - the Global Entrepreneurship Research Association (GERA) (2016): 2015/16 Global Report. http://gemconsortium.org/report/49480, Letöltve: 2016. 08. 19.

KSH (2017): Vállalkozások demográfiája, 2015. Központi StatisztikaiHivatal,Budapest.http://www.ksh.hu/apps/ shop.kiadvany?p_kiadvany_id=936028\&p_temakor_kod=KSH\&p_session_id=300419973154990\&p_ lang=HU, Letöltve: 2017. 12. 14.

Levenson, H. (1974): Activism and powerful others: distinctions within the concept of internal-external control. Journal of Personality Assessment, 38, 377- 383. o.

McGrath, R. (1999): Falling forward: Real options reasoning and entrepreneurial failure. Academy of Management Review, 24, 13-30. o.

McKenzie, B. M. - Sud, M. (2008): A Hermeneutical Approach to Understanding Entrepreneurial Failure. Academy of Entrepreneurship Journal, 14, 2, 123-148. o. 
Orosz G. - Dombi E. - Tóth-Király I. - Roland-Lévy C. (2015): The Less is More: The 17-Item Zimbardo Time Perspective Inventory. Current Psychology, (Preprints), 1-9. o.

Repisky M. (2015): Vállalkozói személyiségjegyek és a vállalkozók megítélése három csoport szemszögéből. In: Udvari B. (szerk.): TDK Mühelytanulmányok II. szám - „Első szárnypróbálgatások”. Szeged: Szegedi Tudományegyetem Gazdaságtudományi Kar, 66-84. o.

Rotter, J. B. (1966): Generalized expectancies of internal versus external control of reinforcement. Psychological Monographs, Medline, 80, 1, 1-28. o.

Sapp, S. G. - Harrod, W. J. (1993): Reliability and Validity of a Brief Version of Levenson's Locus of Control Scale. Psychological Reports, 72, 539-550. o.

Shepherd, D. A. (2003): Learning from business failure: propositions of grief recovery for the self-employed. Academy of Management Review, 28, 2, 318-328. o.

Shepherd, D. A. - Patzelt, H. (2017): Trailblazing in entrepreneurship: Creating new paths for understanding the field. Springer.

Shepherd, D. A. - Wiklund, J. -Haynie, J. M. (2009): Moving forward: Balancing the financial and emotional costs of business failure. Journal of Business Venturing, 24, 2, 134-148. o.

Simmons, S. - Wiklund, J. - Levie, J. (2014): Stigma and business failure: implications for entrepreneurs' career choices. Small Business Economics, 42, 3, 485-505. o.

Singh, S. - Corner, P. - Pavlovich, K. (2007): Coping with entrepreneurial failure. Journal of Management \& Organization, 13, 331-344. o.

Singh, S. - Corner, P. D. - Pavlovich, K. (2015): Failed, not finished: A narrative approach to understanding venture failure stigmatization. Journal of Business Venturing, 30, 1, 150-166. o.

Sitkin, S. B. (1992): Learning through failure: the strategy of small losses. In: Shaw, B. M. - Cummings, L. L. (eds.) (1992): Research in Organisational Behaviour, 14, 231-266. o.

Szerb L. - Kocsis-Kisantal O. (2008): Vállalkozói kultúra Magyarországon két napilap tükrében. Közgazdasági Szemle, 55., 243-261. o.

Ucbasaran, D. - Shepherd, D. - Lockett, A. - Lyon, S. $J$. (2013): Life after business failure: the process and consequences of business failure for entrepreneurs. Journal of Management, 39, 1, 163-202. o.

Ucbasaran, D. - Alsos, G. A. - Westhead, P. Wright, M. (2008): Habitual entrepreneurs. Foundations and Trends ${ }^{\circledR}$ in Entrepreneurship, 4, 4, 309-450. o.

Ucbasaran, D. - Westhead, P. - Wright, M. - Flores, $M$. (2010): The nature of entrepreneurial experience, business failure and comparative optimism. Journal of Business Venturing, 25, 6, 541-555. o.

Wiesenfeld, B. M. - Wurthmann, K. A. - Hambrick, D. C. (2008): The Stigmatization and Devaluation of Elites Associated with Corporate Failures: A Process Model. Academy of Management Review, 33, 1, 231-251. o.

Zimbardo, P. G. - Boyd, J. N. (1999): Putting time in perspective: a valid, reliable individual-differences metric. Journal of Personality and Social Psychology, 77, 6, 1271-1288. o.

Zimbardo, P. G. - Boyd, J. N. (2012): Időparadoxon Hasznosítsd újra a tegnapot, élvezd a mát, és légy úrrá a holnapon. Budapest: HVG Kiadó 